\title{
Evaluation of Radioiodinated 1-[2-(3,4-Dimethoxyphenyl)ethyl]-4-(2- iodophenylpropyl)piperazine as a Tumor Diagnostic Agent with Functional Sigma Receptor Imaging by Single Photon Emission Computed Tomography
}

\author{
Masahiko Hirata,* Tetsuya Mori, Takuya Umeda, Takeshi Abe, Tomoya Yamamoto, and \\ Yoshiro Онмомо
}

Osaka University of Pharmaceutical Sciences; 4-20-1 Nasahara, Takatsuki, Osaka 569-1094, Japan.

Received October 26, 2007; accepted January 23, 2008; published online February 27, 2008

\begin{abstract}
Radioiodinated 1-[2-(3,4-dimethoxyphenyl)ethyl]-4-(2-iodophenylpropyl)piperazine (o-BON) and 1-[2-(3,4dimethoxyphenyl)ethyl]-4-(3-iodophenylpropyl)piperazine $(m-\mathrm{BON})$ were evaluated as single photon emission computed tomography (SPECT) radiopharmaceuticals for tumor imaging by visualization of sigma receptors. In vivo biodistribution studies of $\left[{ }^{125} \mathrm{I}\right] \mathrm{o}-\mathrm{BON}$ and $\left[{ }^{125} \mathrm{I}\right] \mathrm{m}$-BON in tumor-bearing mice showed a high tumor uptake and prolonged retention of radiolabeled compounds in the tumor. In contrast with these factors, the blood and muscle accumulations were low, which resulted in a good tumor-to-blood ratio and tumor-to-muscle ratio. In peripheral organs, $\left[{ }^{125} \mathrm{I}\right] \boldsymbol{o}$-BON showed rapid clearance in comparison with $\left[{ }^{125} \mathrm{I}\right] \mathrm{m}$-BON. Selective interactions of $\left[{ }^{125} \mathrm{I}\right] \boldsymbol{o}$-BON and $\left[{ }^{125} \mathrm{I}\right] \mathrm{m}$-BON with sigma receptors on tumor cell membranes were confirmed by pretreatment experiments with various sigma and other receptor ligands. $\left[{ }^{125} \mathrm{I}\right] \sigma$-BON possesses higher specific binding toward sigma receptors than does $\left[{ }^{125} \mathrm{I}\right] \mathrm{m}$-BON; thus, $\left[{ }^{125} \mathrm{I}\right] \mathrm{o}$-BON was chosen for further evaluations. High uptake of $\left[{ }^{125} \mathrm{I}\right] \boldsymbol{0}$-BON was observed in various tumors, and a good linear correlation $\left(R^{2}=0.70\right)$ was found between accumulation of $\left[{ }^{125} \mathrm{I}\right] \boldsymbol{o}-\mathrm{BON}$ and the sigma receptor expression level. Furthermore, the accumulation of $\left[{ }^{125} \mathrm{I}\right] \boldsymbol{o}-\mathrm{BON}$ in tumors reflected their proliferation rate. These results suggest that it is feasible to use radioiodinated $o$-BON as a marker for measuring the proliferative status associated with sigma receptor expression.
\end{abstract}

Key words radiopharmaceutical; radioiodine; single photon emission computed tomography; sigma receptor; tumor imaging

Sigma receptors were suggested as subtypes of the opiate receptors in 1976 by Martin et al., ${ }^{1)}$ however, later studies of the pharmacological binding and behavioral studies had to be modified that they were non-opiate and non-phencyclidine (PCP) binding site. ${ }^{2)}$ From binding studies, sigma receptors have been classified into at least two subtypes, termed sigma1 and sigma-2, for their pharmacological profiles and different molecular weights. ${ }^{2,3}$ Sigma-1 receptor is a $\mathrm{Mr} 25000$ which protein was purified and cloned from the liver of guinea pig, ${ }^{4)}$ while sigma-2 receptor is a Mr 18000—21000 protein that has not yet been cloned. ${ }^{2,3)}$ Sigma receptors are present not only in the central nervous system but also in other tissues, such as the liver, kidneys, lungs, gonads, and ovaries. ${ }^{5-9)}$ Moreover, sigma receptors are expressed in a variety of human tumors in high densities $(1.0-1.5$ million receptors/cell), such as malignant melanoma, ${ }^{10)}$ non-small-cell lung carcinoma, ${ }^{11)}$ breast cancer, ${ }^{12}$ and tumors of neural origin. ${ }^{13)}$ Interestingly, sigma receptors are highly expressed in rapidly proliferating cells and are down-regulated when cells become quiescent. ${ }^{14-16)}$ Their high density in various tumor cell types, particularly in proliferating cells, makes sigma receptors potential targets for diagnostic imaging.

Several radiolabeled ligands have been developed for the imaging of sigma receptors by single photon emission computed tomography (SPECT) $)^{19-23)}$ and positron emission tomography (PET). ${ }^{24-26)}$ We have explored the feasibility of using radioiodinated sigma receptor ligands for functional sigma receptor studies with SPECT, and have already reported the design, synthesis, and biological evaluation of iodinated SA4503 analogues. ${ }^{27,28)}$ Among them, 1-[2-(3,4dimethoxyphenyl)ethyl]-4-[3-(2-iodophenyl)propyl]piper- azine $(o-B O N)$ and 1-[2-(3,4-dimethoxyphenyl)ethyl]-4-[3(3-iodophenyl)propyl]piperazine ( $m$-BON) (Chart 1), were found to have high affinities to sigma-1 and sigma-2 receptors, comparable to those of SA4503 examined under the same conditions (sigma-1, $o$-BON: $6.4 \mathrm{~nm}, m-\mathrm{BON}: 8.9 \mathrm{~nm}$, SA4503, $4.0 \mathrm{~nm}$, sigma-2, $o-\mathrm{BON}: 10.2 \mathrm{~nm}, m-\mathrm{BON}: 54.5 \mathrm{~nm}$, SA4503: $55.7 \mathrm{nM})$. The radioiodinated derivatives, $\left[{ }^{125} \mathrm{I}\right] \mathrm{o}-$ $\mathrm{BON}$, and $\left[{ }^{125} \mathrm{I}\right] m$-BON were synthesized by the iododestannylation reaction from the corresponding tributyltin precursors with high yields. The binding of $\left[{ }^{125} \mathrm{I}\right] o-\mathrm{BON}$ and $\left[{ }^{125} \mathrm{I}\right] m$-BON have been characterized in rat brain membranes. In vitro blocking studies confirmed the high specificity of $o$-BON and $m$-BON. Radioiodinated $o$-BON and $m$ $\mathrm{BON}$ gave a clear image corresponding to sigma receptor density in the brain, and both had good characteristics for mapping sigma receptors in the central nervous system and in peripheral organs by SPECT. Thus, these radioligands may be used for visualization of sigma receptors in tumors. In the present study, we evaluated their use for tumor imaging by SPECT.

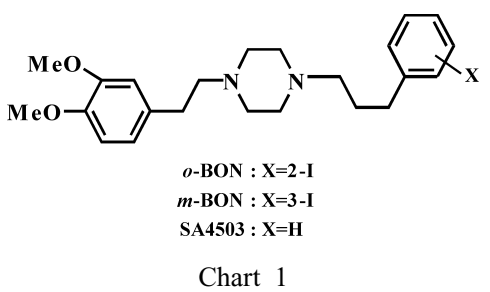

(C) 2008 Pharmaceutical Society of Japan 


\section{RESULTS AND DISCUSSION}

The A375 human malignant melanoma cell line was chosen because it was reported to possess sigma receptors. ${ }^{10)}$ An A375 melanoma-bearing mouse model has been used in the evaluation of several potential tumor imaging agents. ${ }^{18,23,29)}$ As an initial screening to assess the relative potential of $\left[{ }^{125} \mathrm{I}\right] o$-BON and $\left.{ }^{[25} \mathrm{I}\right] m$-BON as diagnostic agents for tumor imaging, biodistribution studies of them were performed in A375 tumor-bearing mice at 2, 6, 12, and $24 \mathrm{~h}$ after intravenous administration. The results are summarized in Tables 1 and 2. The accumulation of $\left[{ }^{125} \mathrm{I}\right] o-\mathrm{BON}$ in the tumor was high, $2.42 \%$ dose $/ \mathrm{g} 2 \mathrm{~h}$ after injection, the tumor radioactivity level decreased gradually to $1.57 \%$ dose/g $2-24 \mathrm{~h}$ after injection. $\left[{ }^{125} \mathrm{I}\right] o-\mathrm{BON}$ exhibited the desired prolonged retention in the tumor $(1.57 \% \mathrm{dose} / \mathrm{g}$ at $24 \mathrm{~h}$ after injection). In contrast with the high tumor uptake and retention of the two agents, these blood accumulations were low, which resulted in good tumor-blood ratios at $24 \mathrm{~h}$ after injection. The tumormuscle ratio of $\left[{ }^{125} \mathrm{I}\right] o-\mathrm{BON}$ at $24 \mathrm{~h}$ was higher than that of

Table 1. Biodistribution of $\left[{ }^{125} \mathrm{I}\right] \mathrm{o}-\mathrm{BON}$ in A375 Tumor Bearing Mice

\begin{tabular}{|c|c|c|c|c|}
\hline \multirow{3}{*}{ Tissue } & \multicolumn{4}{|c|}{ Tissue uptake ${ }^{a)}$} \\
\hline & \multicolumn{4}{|c|}{ Time after injection } \\
\hline & $2 \mathrm{~h}$ & $6 \mathrm{~h}$ & $12 \mathrm{~h}$ & $24 \mathrm{~h}$ \\
\hline Tumor & $2.42 \pm 0.24$ & $2.00 \pm 0.28$ & $1.97 \pm 0.13$ & $1.57 \pm 0.10$ \\
\hline Blood & $0.38 \pm 0.06$ & $0.31 \pm 0.07$ & $0.15 \pm 0.03$ & $0.09 \pm 0.04$ \\
\hline Muscle & $0.93 \pm 0.14$ & $0.46 \pm 0.06$ & $0.33 \pm 0.06$ & $0.23 \pm 0.02$ \\
\hline Pancreas & $18.5 \pm 0.96$ & $19.2 \pm 3.43$ & $15.7 \pm 2.69$ & $7.01 \pm 0.73$ \\
\hline Spleen & $6.46 \pm 0.29$ & $4.10 \pm 0.63$ & $2.55 \pm 0.23$ & $1.24 \pm 0.15$ \\
\hline Stomach & $4.36 \pm 0.54$ & $4.56 \pm 0.53$ & $0.82 \pm 0.28$ & $0.72 \pm 0.15$ \\
\hline Liver & $15.4 \pm 1.79$ & $10.24 \pm 1.70$ & $6.67 \pm 0.86$ & $3.08 \pm 0.45$ \\
\hline Kidney & $7.58 \pm 0.89$ & $5.26 \pm 0.58$ & $4.28 \pm 0.30$ & $2.80 \pm 0.26$ \\
\hline Heart & $1.17 \pm 0.33$ & $0.75 \pm 0.07$ & $0.67 \pm 0.14$ & $0.38 \pm 0.08$ \\
\hline Lung & $4.20 \pm 0.93$ & $2.47 \pm 0.23$ & $2.14 \pm 0.22$ & $1.60 \pm 0.22$ \\
\hline Brain & $2.51 \pm 0.20$ & $2.10 \pm 0.24$ & $1.00 \pm 0.15$ & $0.57 \pm 0.10$ \\
\hline Tumor/muscle ${ }^{b)}$ & $2.6 \pm 0.72$ & $4.3 \pm 0.45$ & $6.0 \pm 1.26$ & $6.8 \pm 0.62$ \\
\hline Tumor/blood $^{b)}$ & $6.4 \pm 1.90$ & $6.5 \pm 2.37$ & $13.4 \pm 5.45$ & $17.2 \pm 7.83$ \\
\hline
\end{tabular}

a) Mean $\%$ injection dose \pm S.D. per gram of four mice. b) Ratio of tumor-toblood or tumor-to-muscle.

Table 2. Biodistribution of $\left[{ }^{125} \mathrm{I}\right] m-\mathrm{BON}$ in A375 Tumor Bearing Mice

\begin{tabular}{|c|c|c|c|c|}
\hline \multirow{3}{*}{ Tissue } & \multicolumn{4}{|c|}{ Tissue uptake ${ }^{a)}$} \\
\hline & \multicolumn{4}{|c|}{ Time after injection } \\
\hline & $2 \mathrm{~h}$ & $6 \mathrm{~h}$ & $12 \mathrm{~h}$ & $24 \mathrm{~h}$ \\
\hline Tumor & $2.75 \pm 0.36$ & $2.15 \pm 0.35$ & $1.94 \pm 0.07$ & $1.78 \pm 0.07$ \\
\hline Blood & $0.41 \pm 0.07$ & $0.32 \pm 0.10$ & $0.18 \pm 0.01$ & $0.10 \pm 0.03$ \\
\hline Muscle & $1.35 \pm 0.30$ & $1.05 \pm 0.10$ & $0.62 \pm 0.02$ & $0.48 \pm 0.05$ \\
\hline Pancreas & $13.5 \pm 0.82$ & $12.8 \pm 0.62$ & $12.2 \pm 2.71$ & $10.3 \pm 1.57$ \\
\hline Spleen & $9.22 \pm 0.82$ & $7.28 \pm 0.94$ & $6.74 \pm 1.07$ & $5.06 \pm 0.31$ \\
\hline Stomach & $2.38 \pm 0.42$ & $2.08 \pm 0.95$ & $1.22 \pm 0.60$ & $1.17 \pm 0.20$ \\
\hline Liver & $18.5 \pm 1.81$ & $15.2 \pm 1.16$ & $18.0 \pm 4.08$ & $12.4 \pm 1.39$ \\
\hline Kidney & $13.7 \pm 1.64$ & $9.78 \pm 0.98$ & $5.91 \pm 0.65$ & $3.78 \pm 0.40$ \\
\hline Heart & $2.92 \pm 0.55$ & $1.92 \pm 0.24$ & $1.17 \pm 0.21$ & $0.79 \pm 0.08$ \\
\hline Lung & $15.5 \pm 1.81$ & $7.77 \pm 0.86$ & $5.08 \pm 0.33$ & $2.86 \pm 0.35$ \\
\hline Brain & $3.15 \pm 0.51$ & $2.48 \pm 0.39$ & $1.92 \pm 0.52$ & $1.95 \pm 0.36$ \\
\hline Tumor/muscle ${ }^{b)}$ & $2.0 \pm 0.45$ & $2.0 \pm 0.64$ & $3.1 \pm 0.57$ & $3.7 \pm 0.51$ \\
\hline Tumor/blood ${ }^{b)}$ & $6.6 \pm 1.53$ & $6.7 \pm 1.18$ & $10.5 \pm 1.29$ & $17.4 \pm 7.25$ \\
\hline
\end{tabular}

a) Mean $\%$ injection dose \pm S.D. per gram of four mice. b) Ratio of tumor-toblood or tumor-to-muscle. $\left.{ }^{125} \mathrm{I}\right] m-\mathrm{BON}$, as a result of the different clearance of each agent from muscle. Each radiotracer exhibited relatively high uptake retention in organs known to possess sigma receptors, including the lung, heart, liver and kidney. $\left[{ }^{125} \mathrm{I}\right] o-\mathrm{BON}$ was observed to more rapidly clear from these organs compared with $\left[{ }^{125} \mathrm{I}\right] m$-BON. In particular, the liver accumulation of $\left[{ }^{125} \mathrm{I}\right] \mathrm{o}$-BON $24 \mathrm{~h}$ after injection was one-third that of $\left[{ }^{125} \mathrm{I}\right] \mathrm{m}$ $\mathrm{BON}$, this clearance from peripheral organs is good characteristic for a radiopharmaceutical for tumor diagnosis.

Next, an in vitro pharmacological blocking study was performed to examine the degree of specific binding of $\left[{ }^{125} \mathrm{I}\right] \mathrm{o}$ BON and $\left.{ }^{125} \mathrm{I}\right] \mathrm{m}$-BON in A375 melanoma membranes. As shown in Fig. 1, the total amount of $\left[{ }^{125} \mathrm{I}\right] o-\mathrm{BON}$ (top panel) or $\left[{ }^{125} \mathrm{I}\right] \mathrm{m}$-BON binding (bottom panel) indicated a significant decrease when pretreated with various sigma ligands, such as SA4503 (sigma-1), ( \pm )-pentazocine (sigma-1), haloperidol (sigma-1, 2, dopamine), DTG (sigma-1, 2), (+)3-PPP (sigma-1, 2), rimcazole (sigma-1, 2), and ( \pm )SKF10047 (sigma-1, 2). In addition, the reduction rate in the radioactivity by pretreatment with these ligands was correlated with the affinity of each sigma ligand. On the other hand, the non-sigma receptor ligands, such as (+)$\mathrm{SCH} 23390\left(\mathrm{D}_{1}\right),(-)$-sulpiride $\left(\mathrm{D}_{2}\right)$, spiperone $\left(\mathrm{D}_{2}, 5-\mathrm{HT}_{2}\right)$, naloxone (opiate), atropine (muscarinic), $(-)$-nicotine (nicotinic), (-)-propranolol $\left(\beta, 5-\mathrm{HT}_{1}\right)$ and phentolamine $(\alpha)$, failed to block the $\left[{ }^{125} \mathrm{I}\right] o$-BON and $\left[{ }^{125} \mathrm{I}\right] m$-BON binding. Binding to sigma receptors was reduced significantly by pretreatment with haloperidol (sigma-1, -2, dopamine). However, neither $\left[{ }^{125} \mathrm{I}\right] o-\mathrm{BON}$ nor $\left[{ }^{125} \mathrm{I}\right] \mathrm{m}$-BON binding was reduced by the pretreatment with $(+)-\mathrm{SCH} 23390\left(\mathrm{D}_{1}\right)$ or $(-)$ -
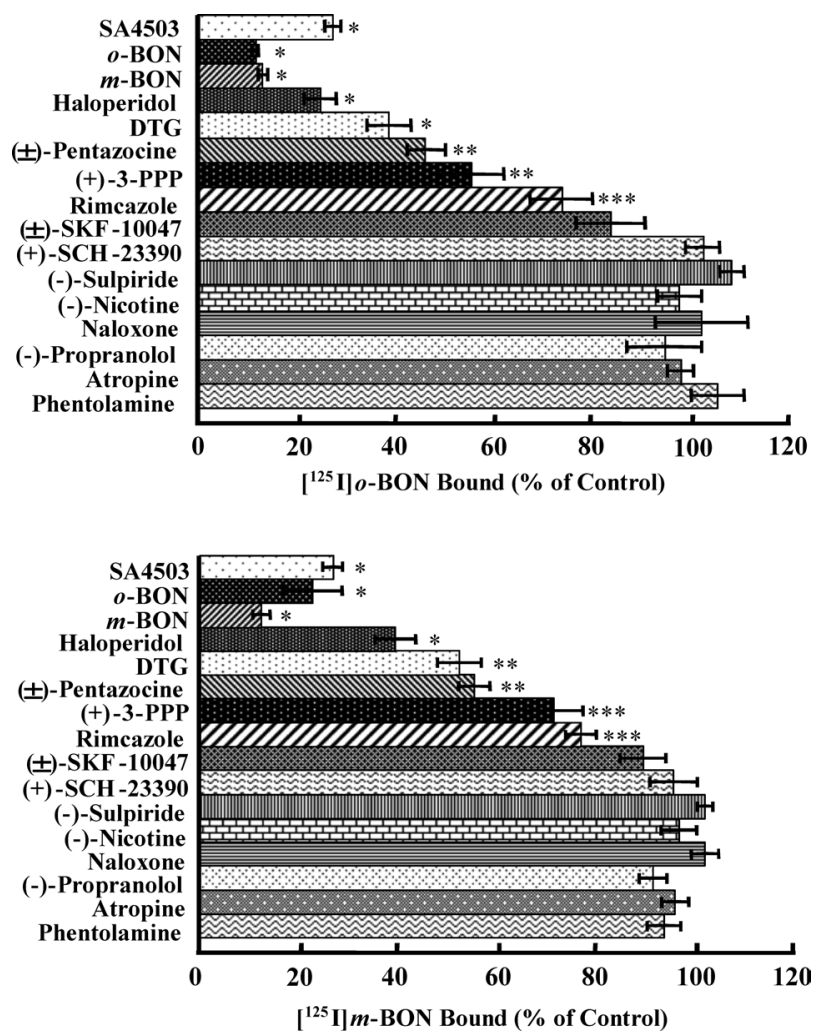

Fig. 1. In Vitro Blocking Effect of Various Receptor Ligands on the Binding of $\left[{ }^{125} \mathrm{I}\right] o-\mathrm{BON}$ (Top Panel) and $\left[{ }^{125} \mathrm{I}\right] m$-BON (Bottom Panel) to Membranes of A375 Cells

Data represent mean \pm S.D. of four mice as percent of the control value. $* p<0.001$, $* * p<0.005, * * * p<0.01$ 

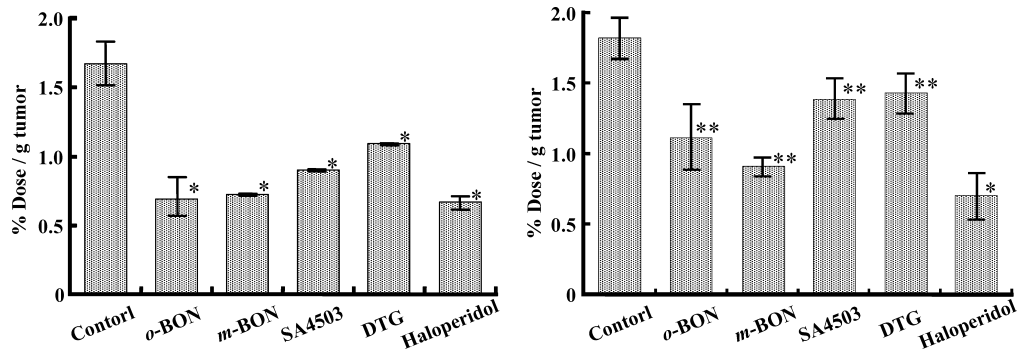

Fig. 2. In Vivo Blocking Effect of Various Sigma Ligands on the Tumor Uptake of $\left[{ }^{125} \mathrm{I}\right] o$-BON (Left) and $\left[{ }^{125} \mathrm{I}\right] m$-BON (Right) in A375 Tumor Bearing Mice

Data represent mean \pm S.D. of four mice. $* p<0.001, * * p<0.005$.

sulpiride $\left(\mathrm{D}_{2}\right)$. These data indicated that the two radioiodinated ligands bound only to sigma receptors.

Further studies of the in vivo selective binding of $\left[{ }^{125} \mathrm{I}\right] \mathrm{o}$ $\mathrm{BON}$ and $\left[{ }^{125} \mathrm{I}\right] m-\mathrm{BON}$ to sigma receptors were carried out by pretreatment with selective and nonselective sigma receptor ligands. The effect of these various ligands on the tumor uptake of $\left[{ }^{125} \mathrm{I}\right] o$-BON and $\left[{ }^{125} \mathrm{I}\right] m$-BON $2 \mathrm{~h}$ after injection is shown in Fig. 2. Pretreatment with the ligands SA4503 (sigma-1), haloperidol (sigma-1, 2, dopamine) DTG (sigma$1,2), o-\mathrm{BON}$, and $m$-BON significantly reduced $\left[{ }^{125} \mathrm{I}\right] o-\mathrm{BON}$ and $\left[{ }^{125} \mathrm{I}\right] m$-BON uptake in a tumor, suggesting that $\left[{ }^{125} \mathrm{I}\right] o$ $\mathrm{BON}$ and $\left[{ }^{125} \mathrm{I}\right] m$-BON accumulate through selective binding to sigma receptors. Comparison of $\left[{ }^{125} \mathrm{I}\right] \mathrm{o}$-BON and $\left[{ }^{125} \mathrm{I}\right] \mathrm{m}$ BON showed different dissociation rate of binding behavior to sigma receptors. The differences of between $\left[{ }^{125} \mathrm{I}\right] o-\mathrm{BON}$ and $\left[{ }^{125} \mathrm{I}\right] m$-BON in the brain and peripheral organs have been reported. ${ }^{28)}$ It has been considered that $\left[{ }^{125} \mathrm{I}\right] m$-BON possesses much more non-specific binding compared with that of $\left[{ }^{125} \mathrm{I}\right] o$-BON. Thus, these differences between $\left[{ }^{125} \mathrm{I}\right] o$ $\mathrm{BON}$ and $\left[{ }^{125} \mathrm{I}\right] m-\mathrm{BON}$ in tumor suggested that $\left[{ }^{125} \mathrm{I}\right] o$-BON possesses higher specific binding toward sigma receptors than the latter. Based on their clearance from peripheral organs and specificity to sigma receptors, the potent compound $\left[{ }^{125} \mathrm{I}\right] \mathrm{o}$-BON was chosen for further evaluation.

The expression of sigma receptors in various tumors may serve as a better biomarker of a tumor's proliferative status. ${ }^{14-16)}$ In vitro studies of tumor cells in a proliferative state showed an 8-10 times higher sigma receptor density than tumor cells in a quiescent state. ${ }^{16)}$ Expression of the sigma receptors parallels the proliferative status of breast tumors implanted in nude mice. ${ }^{15)}$ It was thus suggested that imaging agents with a high affinity for sigma receptors might be useful to measure the proliferative status of human solid tumors in conjunction with PET or SPECT. We observed the expression of sigma receptors in tumor cell lines from various tissues and their cell proliferation rate. To observe tumor expression, the crude membrane fractions from various tumor cells were used for binding experiments. $\left[{ }^{125} \mathrm{I}\right] \mathrm{o}-\mathrm{BON}$ bound to the same binding site of $\left[{ }^{3} \mathrm{H}\right] \mathrm{DTG}$ and $\left[{ }^{3} \mathrm{H}\right]$ pentazocine in rat brain membranes with high affinity. ${ }^{27)}$ Thus, in these experiments, the saturation binding studies were carried out using $\left[{ }^{125} \mathrm{I}\right] o$-BON, by means of Scatchard analysis. These $B_{\max }$ values of the various tumor cell lines examined found to be higher than the expression of sigma receptors in normal cells. We next studied the cell proliferation rate and found an excellent linear correlation $\left(R^{2}=0.875\right)$ between the cell proliferation rate and the expression of sigma receptor in the tumor cells (Fig. 3). These data suggest that the expression of

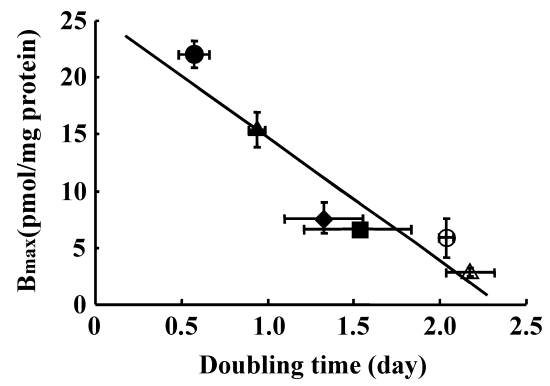

Fig. 3. Relationship between $B_{\max }$ Value of $\left[{ }^{125} \mathrm{I}\right] o-\mathrm{BON}$ in Tumor Cell Membranes and Proliferation Rate of Tumor Cells

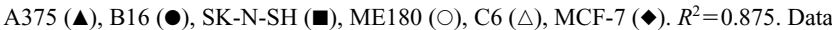
represent mean \pm S.D. of triplicate determinations.

Table 3. Tumor Uptake and Tumor to Tissue Ratio at $24 \mathrm{~h}$ after $\left[{ }^{125} \mathrm{I}\right] o-$ BON Injection in Various Tumor Bearing Mice

\begin{tabular}{lccc}
\hline \hline Cell line & Tumor uptake $^{a)}$ & Tumor/blood $^{b)}$ & Tumor/muscle $^{b)}$ \\
\hline B16 & $2.05 \pm 0.40$ & $54.5 \pm 13.6$ & $14.8 \pm 2.49$ \\
A375 & $1.57 \pm 0.10$ & $17.2 \pm 5.13$ & $6.76 \pm 0.62$ \\
SK-N-SH & $1.41 \pm 0.36$ & $20.1 \pm 6.42$ & $6.13 \pm 1.40$ \\
ME180 & $0.69 \pm 0.13$ & $15.3 \pm 1.85$ & $2.68 \pm 0.64$ \\
C6 & $1.40 \pm 0.16$ & $29.0 \pm 3.02$ & $5.96 \pm 0.80$
\end{tabular}

a) Mean $\%$ injection dose \pm S.D. per gram of four mice. b) Ratio of tumor-toblood or tumor-to-muscle.

sigma receptor reflects tumor cell proliferation.

Moreover, among the various tumor cells used for in vitro studies, tumor-bearing model mice were generated using B16, A375, SK-N-SH, ME180, and C6 tumor cells. In vivo biodistribution studies of $\left[{ }^{125} \mathrm{I}\right] o$-BON were made of these mice at $24 \mathrm{~h}$ after intravenous administration; the results are summarized in Table 3. $\left[{ }^{125} \mathrm{I}\right] o-\mathrm{BON}$ was accumulated in various tumor cell lines, the highest accumulation being observed in B16 melanoma a good tumor-blood ratio and tumor-muscle ratio were found. The accumulation, tumorblood ratio and tumor-muscle ratio of $\left.{ }^{125} \mathrm{I}\right] \mathrm{o}-\mathrm{BON}$ in ME180 were also shown clearly enough to provide an image of the tumor. These results suggest that $\left[{ }^{125} \mathrm{I}\right] o-\mathrm{BON}$ can be used as a radiopharmaceutical for tumor diagnosis in various kinds of tumors.

Furthermore, $\left[{ }^{125} \mathrm{I}\right] o$-BON showed potency as a radiopharmaceutical for the diagnosis of tumor malignancy. A good correlation $\left(R^{2}=0.64\right)$ was also observed in these tumor cells between tumor accumulation of $\left[{ }^{125} \mathrm{I}\right] o-\mathrm{BON}$ and doubling time as cell proliferation rate (Fig. 5). These data show that $\left[{ }^{125} \mathrm{I}\right] \mathrm{o}$-BON provides complementary information on the 


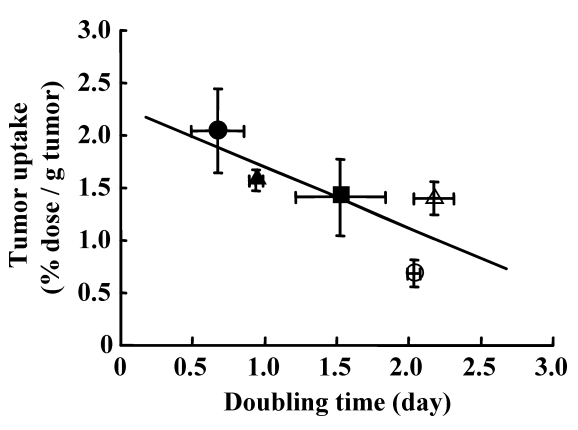

Fig. 4. Relationship between Proliferation Rate of Tumor Cells and in Vivo Tumor Uptake of $\left[{ }^{125} \mathrm{I}\right] o$-BON in Various Tumor Bearing Mice

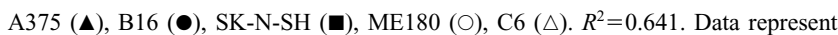
mean \pm S.D. of triplicate determinations.

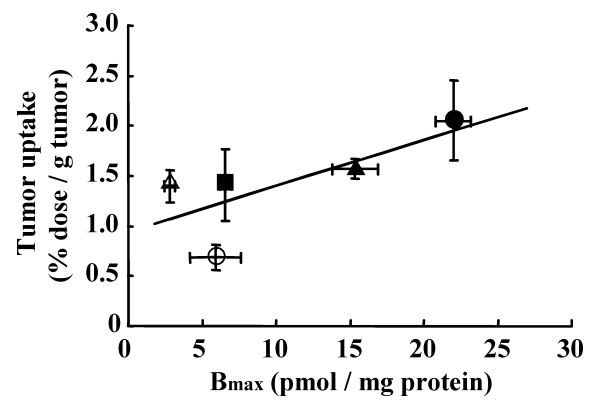

Fig. 5. Relationship between $B_{\max }$ Value of $\left[{ }^{125} \mathrm{I}\right] o-\mathrm{BON}$ in Tumor Cell Membranes and in Vivo Tumor Uptake of $\left[{ }^{125} \mathrm{I}\right] o-\mathrm{BON}$ in Various Tumor Bearing Mice

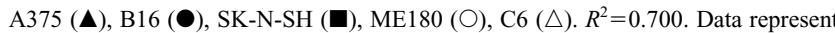
mean \pm S.D. of triplicate determinations.

tumor status. An excellent correlation $\left(R^{2}=0.70\right)$ was observed between accumulation in various tumor-bearing model mice and $\left[{ }^{125} \mathrm{I}\right] o$-BON sigma receptor expression level $\left(B_{\max }\right.$ value) (Fig. 5), suggesting that the agent accumulates in correspondence with changes in sigma receptor density in the tumor. These accumulations thus might reflect the expression of sigma receptor in the tumor. These results of in vitro and in vivo studies suggest that it is feasible to use radioiodinated $o$-BON as a marker for measuring the proliferative status associated with sigma receptor expression.

\section{CONCLUSION}

The biodistribution studies with $\left[{ }^{125} \mathrm{I}\right] o-\mathrm{BON}$ and $\left[{ }^{125} \mathrm{I}\right] \mathrm{m}$ BON showed high tumor uptake and prolonged retention. The tumor-to-blood and tumor-to-muscle radioactivity ratios were high. Pretreatment with various sigma ligands showed selective binding of both agents to sigma receptors. Moreover, the accumulation of $\left[{ }^{125} \mathrm{I}\right] o-\mathrm{BON}$ reflected the density of sigma receptor expression and cell proliferation in the tumor. Thus, radioiodinated $o$-BON provides complementary information on the tumor status. All these characteristics of $\left[{ }^{125} \mathrm{I}\right] \mathrm{o}$-BON suggest that its ${ }^{123} \mathrm{I}$-labeled counterpart, $\left[{ }^{123} \mathrm{I}\right] \mathrm{o}$ $\mathrm{BON}$, would have great potential as a SPECT radiopharmaceutical for tumor diagnosis.

\section{MATERIALS AND METHODS}

$\left[{ }^{125} \mathrm{I}\right] \mathrm{NaI}$ was purchased from GE-Healthcare-bioscience Co., Ltd. (Buckinghamshire, England). All other chemicals used were of reagent grade and were purchased commercially. $\left[{ }^{125} \mathrm{I}\right] o$-BON and $\left[{ }^{125} \mathrm{I}\right] m$-BON were prepared by the method described previously (specific activity, approximately $74 \mathrm{TBq} / \mathrm{mmol}$ ). ${ }^{27)}$ The MTS assay kit used was a Cell Titer 96AQ purchased from Promega corporation (Wisconsin, U.S.A.). The HPLC system employed included a Waters M600 pump, a Lambda-Max 481 ultraviolet detector, a Beckman $170 \mathrm{NaI}$ radioactivity detector, and $\mathrm{a}_{5} \mathrm{C}_{18}$ - $\mathrm{AR}$ column $(10 \times 250 \mathrm{~mm}$, Nacalai Tesque, Kyoto, Japan). Radioactivity was measured using an Aloka (Tokyo, Japan) ARC-300 NaI (Tl) gamma scintillation counter. Male ddY mice and balb/c nude mice were obtained from Japan SLC Inc (Shizuoka, Japan). The animals were kept at least one week before the experiments, and animal chow and drinking water were allowed ad libitum. Animals were housed and experiments were performed according to guidelines stipulated by the Osaka University of Pharmaceutical Sciences Animal Care and Use Committee.

Cell Culture The A375 human melanoma cell line was purchased from Dainippon-Sumitomo Pharma (Osaka, Japan). Other tumor cell lines (B16, SK-N-SH, ME180, C6, and MCF7) were supplied from the Cell Resource Center for Biomedical Research, Tohoku University. All cell lines were cultured in serum-supplemented Dulbecco's modified Eagle's medium (DMEM) containing 10\% heat-inactivated fetal bovine serum at $37^{\circ} \mathrm{C}$. The cells were split weekly into a $1: 10$ ratio using trypsin/ethylene diamine tetraacetic acid (EDTA). They were then transferred to 24 well plates and allowed to grow until reaching confluence (about 0.5 million cells), or were grown in cell culture dishes and detached either using trypsin/EDTA $(0.025 \%)$ or by scraping with a cell scraper into DMEM when they reached confluence.

Binding Studies Crude $\mathrm{P}_{2}$ membrane fractions of tumor cells (A375, B16, SK-N-SH, ME180, C6, and MCF7, $0.1 \mathrm{mg}$ of protein) in Tris- $\mathrm{HCl}(50 \mathrm{~mm}, \mathrm{pH} 8.0)$ were incubated for $90 \mathrm{~min}$ at $25^{\circ} \mathrm{C}$ with $\left[{ }^{125} \mathrm{I}\right] o-\mathrm{BON}$ or $\left[{ }^{125} \mathrm{I}\right] \mathrm{m}$-BON $(1-$ $300 \mathrm{~nm}, 0.74 \mathrm{kBq}$, respectively). The total incubation volume was $1.0 \mathrm{ml}$. Non-specific binding was determined in the presence of haloperidol $(10 \mu \mathrm{M})$. Specific binding was defined as the difference between the total and the nonspecific binding. Assays were terminated by rapid vacuum filtration through Whatman GF/B glass fiber filters presoaked in $0.5 \%$ polyethylenimine for at least $30 \mathrm{~min}$ at room temperature before use, and assayed filters were washed 6 times with $4 \mathrm{ml}$ of icecold $10 \mathrm{~mm}$ Tris- $\mathrm{HCl}$ buffer ( $\mathrm{pH} 7.4)$. The filter-bound radioactivity was measured by a well-type $\mathrm{NaI}(\mathrm{Tl})$ gamma scintillation counter. Saturation binding data were analyzed by Scatchard plot analysis for determination of the equilibrium dissociation constant $\left(K_{\mathrm{d}}\right)$ and the maximal number of binding sites $\left(B_{\max }\right)$.

Blocking Studies Crude $\mathrm{P}_{2}$ membrane fractions of A375 human melanoma cell line $(0.1 \mathrm{mg}$ of protein) were incubated in Tris- $\mathrm{HCl}(50 \mathrm{~mm}, \mathrm{pH} 8.0)$ for $90 \mathrm{~min}$ at $25^{\circ} \mathrm{C}$ with $\left[{ }^{125} \mathrm{I}\right] o-\mathrm{BON}$ or $\left[{ }^{125} \mathrm{I}\right] \mathrm{m}$-BON $(0.74 \mathrm{kBq}, 74 \mathrm{TBq} / \mathrm{mmol})$ and various receptor ligands $(1 \mu \mathrm{M}, 100 \mu \mathrm{l}): o$-BON, $m$-BON, SA4503, haloperidol, rimcazole, DTG, (+)-3-PPP, ( \pm )SKF10047, (+)-SCH23390, (-)-sulpiride, (-)-nicotine, phentolamine, atropine, or naloxone, and assays were studied as described above. The differences between non-treatment and pre-treatment data were examined by Student's paired $t$ tests. 
Measurement of Tumor Cell Doubling Time Tumor cells were seeded in 24-well plates at a concentration of $1 \times 10^{5}$ cells. All tumor cells were maintained in DMEM supplemented with $10 \%$ fetal bovine serum. The tumor doubling time (DT) was calculated by the equation $\mathrm{DT}=(T-T(0)) \times$ $\log 2 /(\log V-\log V(0))$ (where $T-T(0)$ indicates the time period between the two measurements; and $V(0)$ and $V$ denote the tumor volume at two points of measurement by MTS assay).

Tumor-Bearing Mice A suspension of $1 \times 10^{7}$ cells (A375, B16, SK-N-SH, ME180, and C6) in $0.1 \mathrm{ml}$ of medium was inoculated subcutaneously in male balb/c nude mice ( 4 weeks old $20-25 \mathrm{~g}$ ). About 2 weeks (A375, B16, SK-N-SH) or 4 weeks (ME180, C6), thereafter, the solid tumor has grown to optimal size (about $1 \mathrm{~cm}$ in diameter) and was used for biodistribution studies.

Distribution Studies Using A375 Melanoma-Bearing Mice $\left[{ }^{125} \mathrm{I}\right] o-\mathrm{BON}$ or $\left[{ }^{125} \mathrm{I}\right] m-\mathrm{BON}(37 \mathrm{kBq}, 74 \mathrm{TBq} / \mathrm{mmol})$ in $0.1 \mathrm{ml}$ of saline solution was injected intravenously into A375 tumor-bearing mice (6-weeks-old, 20-25g, $n=4$ ) through a lateral tail vein. At the desired time interval after administration, the animals were killed. Samples of blood and tissues of interest were excised and weighed. Radioactivity was measured using a well-type $\mathrm{NaI}(\mathrm{Tl})$ gamma scintillation counter. The results are expressed in terms of the percentage of injected dose per gram of blood or tissues.

Effect of Pretreatment with Various Receptor Ligands on Tumor Uptake For the pretreatment experiment, mice (6-weeks-old, $20-25 \mathrm{~g}, n=4$ ) were given an intravenous injection of various sigma ligands $(10 \mu \mathrm{mol} / \mathrm{kg}) 5 \mathrm{~min}$ before administration of $\left[{ }^{125} \mathrm{I}\right] o-\mathrm{BON}$ or $\left[{ }^{125} \mathrm{I}\right] m-\mathrm{BON}(37 \mathrm{kBq}$, $74 \mathrm{TBq} / \mathrm{mmol}$ ). The animals were killed $2 \mathrm{~h}$ after injection of the radioligands and these distributions were studied as described above. The differences between non-treatment and pre-treatment data were examined by Student's paired $t$-tests.

Distribution Studies Using Various Tumor-Bearing Mice $\left[{ }^{125} \mathrm{I}\right] o-\mathrm{BON}(37 \mathrm{kBq}, 74 \mathrm{TBq} / \mathrm{mmol})$ in $0.1 \mathrm{ml}$ of saline solution was injected intravenously into tumor-bearing mice (A375, B16, SK-N-SH, ME180, and C6, 6-8 weeksold, $20-25 \mathrm{~g}, n=4)$ through a lateral tail vein, and their distributions $24 \mathrm{~h}$ after administration were determined as described above.

Acknowledgements This work was supported by Grants-in-Aid for Scientific Research (C) No. 13670972 and No.17591298 and a Grant-in-Aid for High Technology Research from the Ministry of Education, Culture, Sports, Science and Technology of Japan.

\section{REFERENCES}

1) Martin W. R., Eades C. G., Thompson J. A., Huppler R. E., Gilbert P.
E., J. Pharmacol. Exp. Ther., 197, 517-532 (1976).

2) Walker J. M., Bowen W. D., Walker F. O., Matsumoto R. R., De Costa B. R., Rice K. C., Pharmacol. Rev., 42, 355-402 (1990).

3) Quirion R., Bowen W. D., Itzhak Y., Junien J. L., Rothman R. B., Su T. P., Tam S. W., Taylor D. P., Trends Neurosci., 10, 444 - 446 (1992).

4) Hellewell S. B., Bowen W. D., Brain Res., 527, 244-253 (1990).

5) Hanner M., Moebius F. F., Flandorfer A., Knaus H-G., Striessnig J., Kempner E., Glossmann H., Proc. Natl. Acad. Sci. U.S.A., 93, 80728077 (1996).

6) Hellewell S. B., Bruce A., Feinstein G., Orringer J., Williams W., Bowen W. D., Eur. J. Pharmcol., 268, 9-18 (1994).

7) Wolfe S. A., Jr., Clup S. G., De Souza E. B., Endocrinology, 124, $1160-1172$ (1988).

8) Su T. P., London E. D., Jaffe J. H., Science, 240, 219-221 (1988).

9) Brent P. J., Pang G. T., Eur. J. Pharmcol., 278, 151-160 (1995).

10) John C. S., Bowen W. D., Saga T., Kinuya S., Vilner B. J., Baumgold J., Paik C. H., Reba R. C., Newmann R. D., Varma V. M., McAfee J. G., J. Nucl. Med., 34, 2169-2175 (1993).

11) John C. S., Bowen B. D., Varma V. M., McAfee J. G., Moody T. W., Life Sci., 56, 2385-2392 (1995).

12) John C. S., Vilnear B. J., Bowen B. D., J. Med. Chem., 37, 1737-1739 (1994).

13) John C. S., Vilner B. J., Gulden M. E., Efange S. M. N., Langason R. B., Moody T. W., Bowen W. D., Cancer Res., 55, 3022-3027 (1995).

14) Mach R. H., Smith C. R., Al Nabulsi I., Whirrett B. R., Childers S. R., Wheeler K. T., Cancer Res., 57, 156-161 (1997).

15) Al Nabulsi I., Mach R. H., Sten K., Childers S. R., Wheeler K. T., Br J. Cancer, 81, 925-933 (1999).

16) Wheeler K. T., Wang L. M., Wallen C. A., Childers S. R., Cline J. M., Keng P. C., Mach R. H., Br. J. Cancer, 82, 1223-1232 (2000).

17) Bem W. T., Thomas G. E., Mamone J. Y., Homan S. M., Levy S. M., Rush M. D., Johnson F. E., Coscia C. J., Cancer Res., 51, 6558-6562 (1991).

18) Vilner B. J., John C. S., Bowen W. D., Cancer Res., 55, 408-413 (1995).

19) John C. S., Vilner B. J., Gulden M. E., Efange S. M. N., Langason R. B., Moody T. W., Bowen W. D., Cancer Res., 23, 761-766 (1996).

20) Waterhouse R. N., Chapman J., Izard B., Donald A., Belbin K., O’Brien J. C., Collier T. L., Nucl. Med. Biol., 24, 587-593 (1997).

21) Ludovicus S., Ruth O., Filip D., Waterhouse R. N., Katia V., Peter B., Rudi A. D., Guido S., Nucl. Med. Biol., 32 193-200 (2005).

22) Hau C., Tu Z., Mach R., Kung H. F., Kung M. P., Nucl. Med. Biol., 33, 203-209 (2006)

23) Waterhouse R. N., Collier T. L., Nucl. Med. Biol., 24, 127-134 (1997).

24) Van Waarde A., Buursma A. R., Geke A. P., Hospers, Kawamura K., Kobayashi T., Ishii K., Oda K., Ishiwata K., Vaalburg W., Elsinga P. H., J. Nucl. Med., 45, 1939-1945 (2004).

25) Van Waarde A., Jager P. L., Ishiwata K., Dierckx R. A., Elsinga P. H., J. Nucl. Med., 47, 150-154 (2006).

26) Rowland D. J., Jinbin Z. T., Ponde D., Mach R. H., Welch M. J., J. Nucl. Med., 47, 1041-1048 (2006).

27) Hirata M., Mori T., Soga S., Umeda T., Ohmomo Y., Chem. Pharm. Bull., 54, 470-475 (2006).

28) Hirata M., Mori T., Soga S., Umeda T., Ohmomo Y., Biol. Pharm. Bull., 29, 2009-2015 (2006).

29) Pham T. Q., Berghofer P., Liu X., Greguic L., Dikick B., Ballantyne P., Mattner F., Nguyen V., Loc'k C., Katsifis A., J. Nucl. Med., 47, 13481356 (2007). 